ISSN 1991-8631

Short Communication

http://indexmedicus.afro.who.int

\title{
Study on the conformation of insulin by solvent perturbation and ultraviolet spectroscopy
}

\author{
R. A. UMAR*, S. W. HASSAN, A. LAWAL and S.A. ISA \\ Department of Biochemistry, Usmanu Danfodiyo University, Sokoto Nigeria. \\ *Corresponding author, E-mail: rabiu34@yahoo.com
}

\begin{abstract}
This study attempted to gain an insight of the conformation of insulin using solvent perturbation and ultraviolet spectroscopy. The effects of two solvents, mercaptoethanol and sucrose on the absorption spectrum of Insulin were studied; changes in ionic strength and $\mathrm{pH}$ were used to identify the position of amino acid chromophores. The effect on the absorption spectrum of movement from a non-polar to a polar environment indicates that tyrosine and phenylalanine reside on the surface of insulin protein. The results show that $\mathrm{pH}$ resolved spectral behavior of Insulin in the neighborhood of $290 \mathrm{~nm}$ is determined predominantly by the ionization of imidazole $-\mathrm{NH}^{+}$of histidine. The results, however, do not rule out the possible contribution of the phenol hydroxyl of tyrosine in the spectral behavior.

(C) 2013 International Formulae Group. All rights reserved.
\end{abstract}

Keywords: Insulin conformation, solvent perturbation, ultraviolet spectroscopy.

\section{INTRODUCTION}

Insulin is a polypeptide hormone that is produced by the $\beta$ cells of the Islets of Langerhans within the pancreas. It consist of two peptide chains (Nussey and Whitehead, 2001), A- and B-, linked by two inter-chain disulfide bonds (A7-B7 and A20-B19), and also possess an intra-chain disulfide bond in the A-chain (A6-A11). Disulfide bonds are formed when the precursor protein, proinsulin, is folded in the endoplasmic reticulum prior to packaging into secretory granules (Seung-Gu et al., 2003). The pathways of disulfide formation and the role of disulfides in the folding process have not been clearly understood (Seung-Gu et al., 2003). The number and disposition of the disulfide bonds are highly conserved among the members of the insulin family that include insulin itself, IGF-I and -II (Humbel, 1990), relaxin (Schwabe and McDonald, 1977) and bombyxin (Nagata et al., 1995).

Insulin binding to its receptor (Insulin receptor) on the membrane leads to a cascade of events that eventually activates the genes that control glucose and energy regulation (Jackson, 2008). The insulin receptor is a transmembrane tyrosine kinase belonging to the tyrosine kinase receptor family (Farese et al., 2005). The effects of insulin are initiated on receptor occupancy through insulin receptor-mediated phosphorylation of tyrosine residues on the receptor substrate proteins (Farese et al., 2005), activation of phosphatidylinositol 3-kinase (PI3K), which by means of increasing PI-3,4,5-triphosphate 
(PIP3) brings about recruitment of atypical protein kinase $\mathrm{C}$ and protein kinase $\mathrm{B}$ (also known as Akt (Farese et al., 2005), and ultimately the activation of downstream protein kinases and other target proteins (Saini, 2010).

The amino acid cysteine plays an important role in proteins structure and function due to the presence of disulfide bridges. There is evidence that modification of the cysteine residues in Insulin affects its biological activity as well as its conformation. [Hcy7,20-A] insulin, an insulin analogue in which two inter-chain disulfide bonds (A7-B7 and A20-B19) are elongated by a methylene group, has low biological activity (Cosmatos and Katsoyannis, 1975). In addition, change of cysteine residues A6, A7, A11 or B7 in insulin analogues to the D-form dramatically lowers its biological activity (Marki et al., 1997).

Proteins execute important tasks in the metabolic process of cells. To play these roles they must fold or assume particular conformation. Structural and conformational studies of proteins have been pursued by various physical methods such as X-ray, CDR, CD, NMR and crystallography under vastly different conditions (Perez-Paya et al., 1996; Kelly and Price, 2000; Ulmer et al., 2003; Bax 2003). Most of these techniques require expensive equipments for data acquisition or extensive technical knowledge to analyse the data. On the other hand, Ultraviolet (UV) method is a laboratory technique devoid of these requirements (Melo et al., 1995). UV absorbance change following tyrosyl ionization has been used to monitor changes in protein conformation. Melo et al., (1997) used UV absorbance to study thermal unfolding of proteins at high $\mathrm{pH}$ range. Literature regarding the use of solvent perturbation and UV spectroscopy to study the conformation of insulin is very scarce. In this research we employed the use of solvent perturbation and UV spectroscopy to investigate the change in conformation of insulin.

\section{MATERIALS AND METHODS}

Lente insulin (Pig) was purchased from NOVO Nordisk (A/S), Denmark; Mercaptoethanol from Sigma Aldrich Chemical Com., USA. All other chemicals were from BDH Chemical Ltd., Pole, England unless otherwise stated.

\section{Solvent perturbation Method 1}

Four $\mathrm{mL}$ of $20 \%$ glucose solution was pipetted into a test tube to which was added $0.5 \mathrm{ml}$ of insulin (equivalent to $20 \mathrm{IU}$ ). The mixture was then transferred into a quartz cuvette and absorbance-wavelength scanning performed from 200 to $400 \mathrm{~nm}$ using UVvisible spectrophotometer (Pharmacia Ltd, USA), and $20 \mathrm{~mL}$ of glucose solution as blank.

\section{Method 2}

Two $\mathrm{mL}$ of $20 \%$ glycerol solution were transferred into a cuvette to which was added $0.5 \mathrm{ml}$ insulin. The mixture was allowed to equilibrate for 30 mins. Absorbancewavelength scanning was performed from 200 to $400 \mathrm{~nm}$ after zeroing with $20 \%$ glycerol solution.

\section{Method 3:}

Two mls of $0.1 \%$ mercaptoethanol solution were transferred into a cuvette to which was then added $0.5 \mathrm{ml}$ insulin and allowed to equilibrate for 30 mins. Absorbance was measured from 200 to 400 $\mathrm{nm}$ after zeroing with same solution of marcaptoethanol.

\section{Method 4:}

Two ml each of $0.015 \mathrm{M} \mathrm{NaCl}$ and 0.15 $\mathrm{M} \mathrm{NaCl}$ solutions were transferred into separate cuvettes. Then $0.5 \mathrm{ml}$ of insulin was added into each cuvette. Equilibration was allowed for 30 mins and absorbance read from 200 to $400 \mathrm{~nm}$.

\section{Spectrophotometric pH titration}

$\mathrm{M}$ citrate and $0.1 \mathrm{M}$ disodium hydrogen phosphate were used to prepare Macllaine's buffer of varying $\mathrm{pH}$ ranging from 2 to 8 . To each of these solutions was added $0.5 \mathrm{ml}$ insulin. Equilibration was allowed for $30 \mathrm{mins}$ and absorbance read from 200 to $400 \mathrm{~nm}$, 
after blanking with the various solutions. The effects of $\mathrm{pH}$ change on the absorption at 290 $\mathrm{nm}$ were fitted to the Henderson-Hasselbalch equation using a computer programme.

\section{RESULTS AND DISCUSSION}

The optical spectrum of pig insulin (20 UI), in $0.15 \mathrm{M} \mathrm{NaCl}$ (pH 7) shows a maximum peak absorptions at 208, 237 and $272 \mathrm{~nm}$ respectively while the minimum absorption was recorded at $225 \mathrm{~nm}$ wavelength (Figure 1).

The spectrum also showed in 0.015 sodium chloride solution ( $\mathrm{pH}$ 7.0) maximum peak absorption at wavelength $329.5 \mathrm{~nm}$ and minimum absorption at $329 \mathrm{~nm}$. In figure 2, 20 (IU) insulin in $0.015 \mathrm{M} \mathrm{NaCl}$, the absorption spectrum shows maximum absorption at $255 \mathrm{~nm}$.

As shown in Figure 3, the optical spectrum of pig insulin occurred maximally at $255 \mathrm{~nm}$ and minimum absorption at $225 \mathrm{~nm}$ in $20 \%$ glucose $\mathrm{pH}$ of 7.0. Mercaptoethanol (0.1\%.solution) produced a dramatic obliteration of absorption consequent upon reduction in disulfide bonds between the sulfur of cysteine residues (Figure 4).

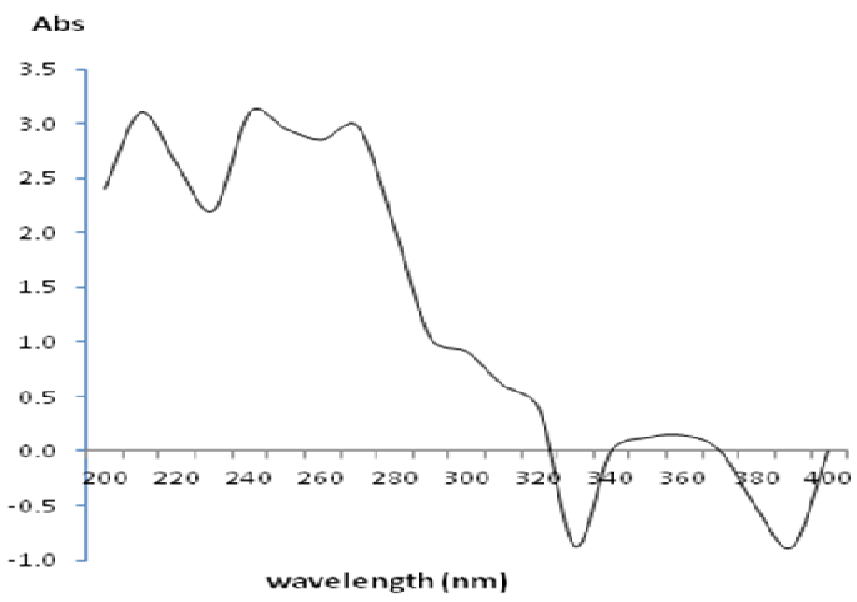

Figure 1: Optical spectrum of pig insulin (20 IU) in $0.15 \mathrm{M} \mathrm{NaCl}(\mathrm{pH} 7.0)$.

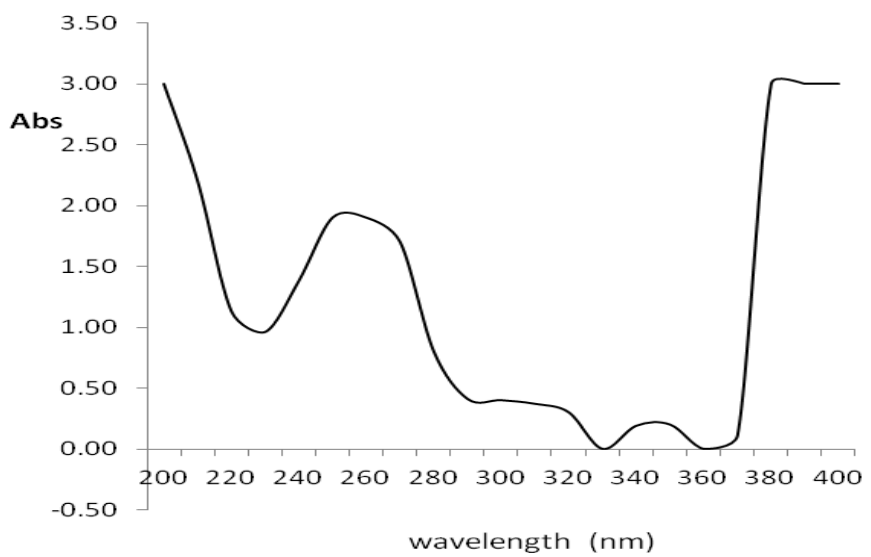

Figure 2: Optical spectrum of pig insulin (20 IU) in 20\% glycerol (pH 7.0). 


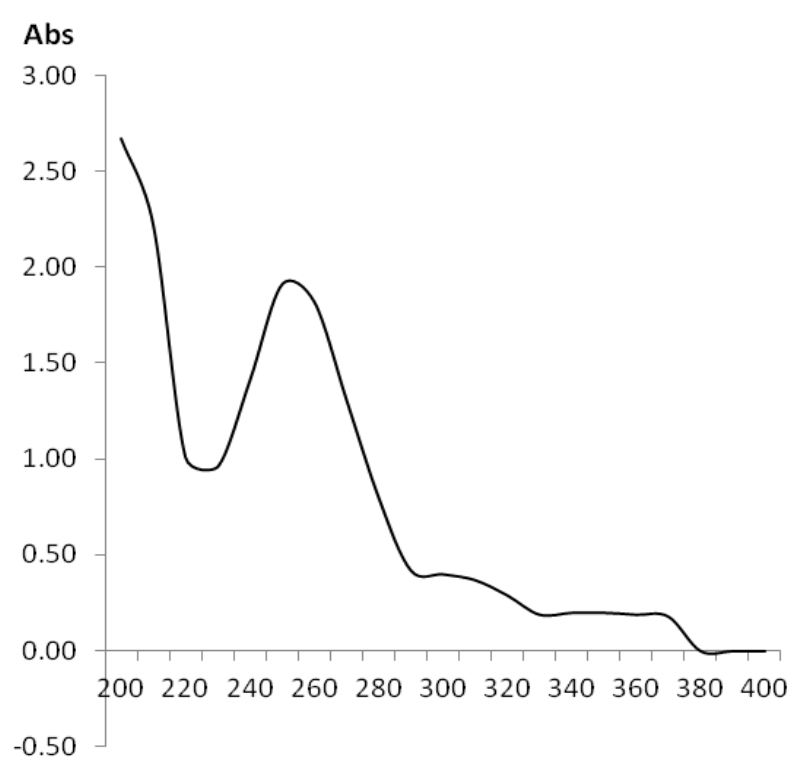

Figure 3: Optical spectrum of pig insulin (20 IU) in glucose.

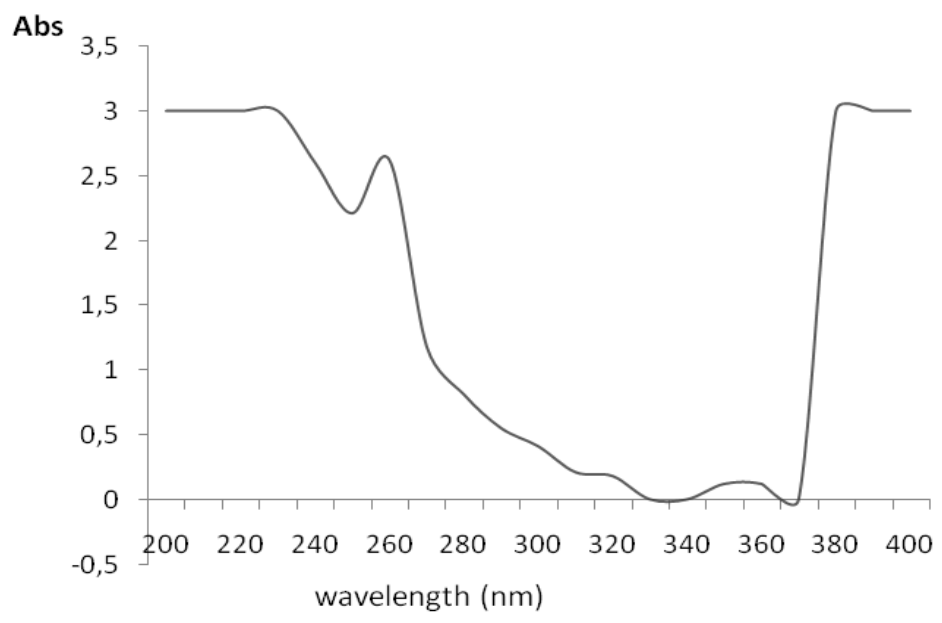

Figure 4: Absorption spectrum of insulin (20 IU) in $0.1 \%$ mercaptoethanol.

In $0.15 \mathrm{M} \mathrm{NaCl}(\mathrm{pH} 9.0)$ the peak of maximum absorption occurs at wavelength $220 \mathrm{~nm}$, and minimum absorption at $240 \mathrm{~nm}$. The peak absorption shifted dramatically from $220 \mathrm{~nm}$ to $260 \mathrm{~nm}$ when the $\mathrm{pH}$ was changed from 9.0 to 10.0 .
To gain insight into the conformation of insulin under different $\mathrm{pH}$, we employed the use of solvent perturbation and UV spectroscopy to investigate the change in conformation of insulin at various $\mathrm{pH}$ values in the presence of $\mathrm{NaCl}$, glucose, or mercapthoethanol. These reagents resulted in 
different spectra for insulin. In line with Freifelder's observation (Freifelder, 1976), the different spectra in $0.15 \mathrm{M} \mathrm{NaCl}$ were due to the presence of aromatic amino acids; tyrosine and phenylalanine. The reported absorption maxima of tyrosine at neutral $\mathrm{pH}$ were 193 , 222 and $274 \mathrm{~nm}$. Our value of 272 as the absorption maxima was near that of tyrosine (272). The absorption maxima of phenylalanine (257, 260 and $188 \mathrm{~nm})$ (Freifelder, 1976) were confirmed by our study.

Ionic strength changes have modification effects on absorption of electromagnetic radiation by insulin. This could be due to the effect of ions on tyrosine and phenylalanine (Murakami et al., 1981; Rehms and Callis, 1993). These changes affect the ionization states of these amino acids and hence the interaction with radiation.

As non-electrolytic solutes, sugars (glucose and glycerol) affect the extinction of the main absorption band (Murakami et al., 1981). The suggested amino acid in the insulin molecule which could contribute to the maximum absorption at these wavelengths is not affected by the presence of glucose and glycerol. The effect of $\mathrm{NaCl}$ is on the ionic strength, which affects the phenolic hydrogen in amino acids that are responsible for the maximum absorption. Tyrosine residues in the insulin possess this phenolic hydrogen hence, it is responsible for the shift observed in the absorption maxima (Pinho Melo et al., 1997).

Tamburo et al., (1970) showed that mercaptoethanol reduces the disulfide bonds between two cysteine residues. The $\mathrm{S}-\mathrm{S}$ bond functions to stabilize the folded structure in the specific form necessary for biological activity rather than to achieve the protein conformation. In addition, Frederick (1982) reported that mercaptoethanol causes the cleavage of disulfide bonds in lysozymes from chicken egg. Our study shows that mercaptoethanol has effect on the absorption spectrum which could be as a result of reduction in disulfide bonds between the sulfur of two cysteine residues. This is in agreement with Sordari and Soltani (2009) who reported obliteration of absorption of human insulin as a result of addition of reagents that caused modification of sulfide bond.

It can be concluded from solvent perturbation approach used in this study that the chromophore amino acids, tyrosine and phenylalanine that brought about changes in the absorption maxima of the Pig insulin (20 UI) when the polarity of the solvent was changed from $0.15 \mathrm{M} \mathrm{NaCl}$, a polar solvent to non-polar solvents, are on the surface of the insulin molecule and not buried within (Freifelder, 1976).

\section{REFERENCES}

Bax A. 2003. Weak alignment offers new NMR opportunities to study protein structure and dynamics. Protein Sci., 12(1): 1-16.

Cosmatos A, Katsoyannis PG. 1975. Elongation of the interchain disulfide bridges of insulin. A synthetic analog. $J$. Biol. Chem., 250: 5315-5321.

Farese RV, Sajan MP, Standaert ML. 2005. Insulin-sensitive protein kinases (atypical protein kinase $\mathrm{C}$ and protein kinase B/Akt): actions and defects in obesity and type II diabetes. Experimental Biology and Medicine, 290(9): 593-605.

Freifelder D. 1976. Physical Biochemistry. Freeman $\mathrm{WH}$ and Company: San Francisco; 384-395.

Humbel RE. 1990. Insulin-like growth factors I and II. Eur. J. Biochem., 190: 445-462.

Jackson C. 2006. Diabetes: kicking off the insulin cascade. Nature, 444(7121): 833844.

Kelly SM, Price NC. 2000. The use of Circular Dichroism in the investigation of protein structure and function. Current Protein and Peptide Science, 1(4): 349384.

Marki F, de Gasparo M, Eisler K, Kamber B, Riniker B, Rittel W, Sieber P. 1979. Synthesis and biological activity of seventeen analogues of human insulin. Hoppe-Seyler's Z. Physiol. Chem., 360: 1619-1632. 
Melo EP, Aires-Barros MR, Costa SM, Cabral JM. 1997. Thermal unfolding of proteins at high $\mathrm{pH}$ range studied by UV absorbance. J. Biochem. Biophys. Methods, 34(1): 45-59.

Mole EP, Aires Barros MR, Cabral JMS. 1995. Triglycerides Hydrolysis and Stability of a recombinant catinase from furarium solani in AOT-180-octane reversed micelles, App. Biochem. Biotech., 50: 45-56.

Murakami A, Mimoru M, Ohkikari, Fujita Y. 1981. Protein Strucure, a Practical Approach. IRL Press: Oxford; 311-330.

Nagata K, Hatanaka H, Kohda D, Kataoka H, Nagasawa $H$, Isogai A, Ishizaki $H$, Suzuki A, Inagaki F. 1995. Threedimensional solution structure of bombyxin-II an insulin-like peptide of the silkmoth Bombyx mori: structural comparison with insulin and relaxin. $J$. Mol. Biol., 253: 749-758.

Pérez-Payá E, Forood B, Houghten RA, Blondelle SE. 1996. Structural characterization and 5'-mononucleotide binding of polyalanine beta-sheet complexes J. Mol. Recognit., 9(5-6): 488493.
Pinho Mole E, Aires - Barros MR, Costa SMB, Cabral JMS. 1997. Journal of Biochemical and Biophysical Methods, 34: 45-59.

Rehms AA, Callis PR. 1993. Two-photon fluorescene excitation spectra of aromatic amino acids. Chemical Physics Letters 208(3-4): 276-282.

Saini V. 2010. Molecular mechanisms of insulin resistance in type 2 diabetes mellitus. World Journal of Diabetes, 1(3): 68-75.

Schwabe C, McDonald JK. 1977. Relaxin: a disulfide homolog of insulin. Science, 197: 914-915.

Sordari S, Soltani S. 2009. Neural network modeling in Dithiothreitol reduction and ion treatment of recombinant human insulinobtained from the circular dichroism (CD) spectral information. The Open Bioinformatics Journal, 3:1-7

Ulmer TS, Ramirez BE, Delaglio F, Bax A. 2003. Evaluation of backbone proton positions and dynamics in a small protein by liquid crystal NMR spectroscopy. $J$. Am. Chem. Soc., 125(30): 9179-9191. 